\title{
EUROPEJSKI STANDARD DOŚWIADCZEŃ NA ZWIERZĘTACH. ASPEKTY HUMANITARNO-PRAWNE
}

\section{EUROPEAN STANDARD OF ANIMAL TESTING. HUMANITARIAN AND LEGAL ASPECTS}

\begin{abstract}
STRESZCZENIE
Postęp w badaniach naukowych z zakresu medycyny, weterynarii jak również dynamiczny rozwój przemysłu farmaceutycznego powoduje zwiększone zapotrzebowanie na wykorzystywanie zwierząt laboratoryjnych. Chronologicznie pierwszym aktem rangi międzynarodowej wprowadzającym istotne ograniczania w eksploatacji zwierząt dla celów naukowych była Europejska Konwencja w sprawie ochrony zwierząt kręgowych wykorzystywanych do celów doświadczalnych i innych celów naukowych sporządzona w Sztrasburgu dnia 18 mar-

" Doktor nauk prawnych, Kujawsko-Pomorska Szkoła Wyższa w Bydgoszczy.
\end{abstract}


ca 1986r. Konwencja ta wraz z dyrektywą Parlamentu Europejskiego i Rady 2010/63/UE z dnia 22 września 2010 r. w sprawie ochrony zwierząt wykorzystywanych do celów naukowych - konstytuuje nowy, europejski standard doświadczeń na zwierzętach. Wiodącą podstawą aksjologiczną standardu jest zasada 3R (od ang. replacement, reduction, refinement) czyli - zastąpienia, zmniejszenia i doskonalenia. Celem niniejszego artykułu jest przedstawienie najważniejszych zasad i wymogów europejskiego standardu doświadczeń na zwierzętach wyznaczonego przez źródła międzynarodowe i unijne ze szczególnym uwzględnieniem aspektów humanitarno-prawnych zawartych w dyrektywie 2010/63/UE.

\section{Słowa kluczowe}

Humanitarne prawo ochrony zwierząt, Światowa Deklaracja Praw Zwierząt, doświadczenia na zwierzętach, zwierzęta laboratoryjne, dobrostan zwierząt, zasada 3R: zastąpienia, zmniejszenia i doskonalenia, dyrektywa 2010/63/UE, ujednolicona skala inwazyjności doświadczeń.

\section{ABSTRACT}

Progress in medical and veterinary research as well as the development of the pharmaceutical industry have influenced the increased need for the usage of laboratory animals. The first act of international law introducing substantial limits on the usage of animals for scientific purposes was the European Convention for the Protection of Vertebrate Animals used for Experimental and Other Scientific Purposes adopted on the $18^{\text {th }}$ of march 1986 in Strasbourg. The Convention along with the European Parliament and Council directive of 22.09.2010 on the protection of animals used for scientific purposes (2010/63/UE) creates a new European standard of animal testing. The axiological ground of this standard is the so called $3 \mathrm{R}$ principle (replacement, reduction, refinement). The objective of this article is the presentation of the most significant rules and requirements of animal experimentation standards set by the acts of international law and European Union documents, especially considering the humanitarian and legal aspects of the above mentioned directive.

\section{Keywords}

Humanitarian animal protection law, Universal Declaration of 3/2012 Animal Rights, animal experimentation, lab animals, animal welfare,

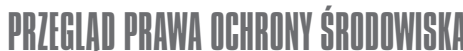


the 3R principle, the directive 2010/63/UE, standardized scale of invasiveness of animal experiments.

\section{WPROWADZENIE}

Prawo humanitarnej ochrony zwierząt pojawiło się ustawodawstwach krajowych w początkach XX wieku - w Polsce reprezentował je postępowy jak na owe czasy akt z 1928 roku$^{1}$. Prawo to powstało z pobudek etycznych. Jego początkowym celem była ochrona zwierząt przed znęcaniem się, z biegiem czasu do zakazów znęcania dołączył również zakaz nieuzasadnionego zabijania. Stymulujący wpływ na rozwój tych uregulowań miało przyjęcie w Paryżu w 1977 r. Światowej Deklaracji Praw Zwierząt. Wprowadziła ona pryncypia etyczne kreujące relacje: człowiek - zwierzę. Należą do nich zasady: humanitarnego traktowania, dereifikacji (zwierzę nie jest rzeczą) i ochrony życia derogowanej jedynie przez ważne potrzeby społeczne. Deklaracja wprowadziła reguły traktowania odnoszące się odpowiednio od zwierząt dzikich, domowych, gospodarskich zwracając również uwagę na los zwierząt laboratoryjnych. Stosownie do jej przepisów doświadczenia na zwierzętach wiążące się z cierpieniem fizycznym i psychicznym są pogwałceniem praw zwierząt, zarówno w przypadku doświadczeń medycznych, naukowych, handlowych jak i wszystkich innych (art.8a). Należy w tym celu stosować metody zastępcze (art.8b). Wynika z tego, że choć Deklaracja zasadniczo postuluje zastępowanie doświadczeń na zwierzętach innymi metodami badawczymi dopuszcza jednak bezbolesne doświadczenia laboratoryjne (takie jak na przykład obserwacje behawioralne) i przeprowadzanie doświadczeń w znieczuleniu. Warto podkreślić, że pomimo swego niewiążącego charakteru Deklaracja wyznaczyła nowe kierunki rozwoju humanitarnej ochrony zwierząt $\mathrm{w}$ prawie międzynarodowym, unijnym i krajowym.

1 Por. Rozporządzenie Prezydenta RP z dnia 22 marca 1928 r. - o ochronie zwierząt, tj. Dz. U. z 1932, Nr 42. poz. 417. 
Celem niniejszego artykułu jest przedstawienie najważniejszych zasad i wymogów europejskiego standardu doświadczeń na zwierzętach wyznaczonego przez źródła międzynarodowe i unijne ze szczególnym uwzględnieniem aspektów humanitarno-prawnych zawartych w dyrektywie 2010/63/UE.

\section{PRZEGLĄD ŹRÓDEŁ PRAWA}

W związku z rosnącym wykorzystywaniem zwierząt zarówno $\mathrm{w}$ przemyśle farmaceutycznym jak i do badań naukowych ${ }^{2}$ niezbędnym stało się przyjęcie szczegółowych regulacji. Chronologicznie pierwszym aktem rangi międzynarodowej wprowadzającym istotne ograniczania $\mathrm{w}$ eksploatacji zwierząt dla celów naukowych była Europejska Konwencja w sprawie ochrony zwierząt kręgowych wykorzystywanych do celów doświadczalnych i innych celów naukowych sporządzona w Sztrasburgu dnia 18 marca 1986 r. $^{3}$ Weszła ona w życie 1 stycznia 1991 r., a od roku 1998 Unia Europejska jest jedną ze stron tej konwen-

2 Spotyka się różne dane odnośnie skali zwierząt wykorzystywanych dla celów naukowych i medycznych. J. Białocerkiewicz podaje, że „rok rocznie w USA wiwisekcji poddawanych jest według ostrożnych szacunków 17 milionów zwierząt ale nie wyklucza się, że liczba ta może sięgać 70 milionów" (J. Białocerkiewicz, Status prawny zwierząt. Prawa zwierząt czy prawna ochrona zwierząt, Toruń 2005, s. 269). Źródła internetowe związane z organizacjami pro-animalistycznymi utrzymują, że w europejskich laboratoriach co kilka sekund umiera zwierzę poddawane wiwisekcji. Tak alarmującej skali zjawiska bynajmniej nie potwierdzają dane z Polski. W świetle sprawozdania Krajowej Komisji Etycznej w roku 2009 w polskich laboratoriach wykorzystano 209565 zwierząt. W przeważającej ilości były to myszy, szczury, świnki morskie, króliki i inne gryzonie. Przy czym koniecznie należy podkreślić, że liczba zwierząt wykorzystanych nie jest równoznaczna z liczbą zwierząt uśmierconych -choć brak jest tu danych szczegółowych można założyć, że ta ostatnia jest dużo niższa. http://www.nauka.gov.pl/nauka/krajowa-komisjaetyczna-ds-doswiadczen-na-zwierzetach/sprawozdania/

3 Tekst polski konwencji w: Wybór konwencji Rady Europy, Warszawa 1999, s. 493-505. 
cji $^{4}$. Polska jak dotąd, nie ratyfikowała i nie podpisała tej umowy, niemniej w związku z przystąpieniem do UE zostaliśmy, jako kraj, zmuszeni do implementacji dyrektyw unijnych będących $\mathrm{w}$ istocie narzędziami wykonawczymi tej konwencji.

Natomiast pierwszym aktem unijnym odnoszącym się do przedmiotowej problematyki była dyrektywa Rady 86/609/EWG z dnia 24 listopada 1986 r. w sprawie zbliżenia przepisów ustawowych, wykonawczych i administracyjnych Państw Członkowskich dotyczących ochrony zwierząt wykorzystywanych do celów doświadczalnych i innych celów naukowych $^{5}$ obszernie znowelizowana w dyrektywą 2003/65/WE Parlamentu Europejskiego i Rady z dnia 22 lipca 2003 r. zmieniającą dyrektywę Rady 86/609/EWG w sprawie zbliżenia przepisów ustawowych, wykonawczych i administracyjnych Państw Członkowskich dotyczących ochrony zwierząt wykorzystywanych do celów doświadczalnych i innych celów naukowych ${ }^{6}$.

W 2010 roku Parlament Europejski i Rada przyjęli nową dyrektywę - 2010/63/UE z dnia 22 września 2010 r. w sprawie ochrony zwierząt wykorzystywanych do celów naukowych ${ }^{7}$. Jej uchwalenie stało się konieczne z kilku powodów. Po pierwsze, upływ ponad 20 lat od uchwalenia pierwszej dyrektywy i dokonany w tym czasie postęp wiedzy oraz oczekiwań etycznych względem sposobu traktowania zwierząt w laboratoriach uczynił rudymentarne rozwiązania przyjęte $\mathrm{w}$ poprzedniej dyrektywie anachronicznymi ${ }^{8}$. Po drugie, w ciągu ostatnich 20 lat poszanowanie dobrostanu zwierząt stało się jedną z wartości realizowanych przez Unię Europejską wprost uznanych w jej prawie traktatowym -najpierw w Protokole dodatkowym nr 33 do Traktatu Amsterdamskiego, a następnie - w wyniku wej-

4 Dnia 23 marca 1998 r. Rada przyjęła decyzję 1999/575/WE dotyczącą zawarcia przez Wspólnotę Europejskiej konwencji w sprawie ochrony zwierząt kręgowych wykorzystywanych do celów doświadczalnych i innych celów naukowych, Dz. Urz. UE L 222 z 24.8.1999, s. 29.

5 Dz. Urz. UE L 358 z 18.12.1986.

6 Dz. Urz. UE L 230 z 16.09.2003.

Dz. Urz. UE L 276 z 20.10. 2010, s. 33.

8 T. Pietrzykowski, Nowa dyrektywa o doświadczeniach na zwierzętach wątpliwości, wyzwania i szanse, „Prawo i Medycyna” z 2011, nr 2/32, s. 1. 
ścia w życie Traktatu Lizbońskiego - w zmienionym brzmieniu art. 13 Traktatu o funkcjonowaniu Unii Europejskiej ${ }^{9}$. Do zmian przyczyniła się również opinia publiczna wyrażająca zaniepokojenie, ze względów etycznych, wykorzystywaniem zwierząt w tych procedurach. Dyrektywa 2010/63/UE jest obecnie nie tylko podstawowym narzędziem wykonawczym Europejskiej Konwencji w sprawie ochrony zwierząt kręgowych wykorzystywanych do celów doświadczalnych i innych celów naukowych ale aktem, który rozwija, uszczegółowia i precyzuje zawarte w tej konwencji zasady.

Co się zaś tyczy ustawodawstwa krajowego problematyka doświadczeń na zwierzętach początkowo uregulowana była w ustawie z dnia 21 sierpnia z 1997 roku o ochronie zwierząt ${ }^{10}$. Jednakże w związku ze wstąpieniem Rzeczpospolitej do struktur Unii Europejskiej i koniecznością transpozycji szczegółowej, obszernej materii unormowanej dyrektywą 86/609/EWG ustawodawca krajowy zdecydował się na uchylenie stosownego rozdziału ustawy o ochronie zwierząt i uchwalenie w 2005 r. nowej, odrębnej regulacji - ustawy o doświadczeniach na zwierzętach ${ }^{11}$. Aktualnie przed ustawodawcą krajowym stoi konieczność nowelizacji tejże ustawy celem wdrożenia nowych wymogów unijnych, termin transpozycji dyrektywy upływa dnia 1 stycznia $2018 \mathrm{r}$.

9 Dz. U. z 2004 r. Nr 90, poz. 864/2 ze zm., dalej cyt.: TFUE. Artykuł 13 TFUE w brzmieniu nadanym Traktatem z Lizbony ma następującą treść: „Przy formułowaniu i wykonywaniu polityki rolnej, rybołówstwa i transportu Unii oraz jej polityk dotyczących rynku wewnętrznego, badan i rozwoju technologicznego oraz przestrzeni kosmicznej, Unia i Państwa Członkowskie w pełni uwzględniają wymagania w zakresie dobrostanu zwierząt jako istot zdolnych do odczuwania, przy równoczesnym przestrzeganiu przepisów prawnych i administracyjnych oraz zwyczajów Państw Członkowskich związanych w szczególności z obyczajami religijnymi, tradycjami kulturowymi i dziedzictwem regionalnym".

10 Tj. Dz. U. z 2003 r. Nr 106, poz. 1002 ze zm.

11 Dz. U. 2005 r. Nr 33, poz. 289 ze zm. 


\section{ZASADA 3 R JAKO PODSTAWA EUROPEJSKIEGO STANDARDU PROCEDUR NA ZWIERZĘTACH}

\subsection{UWAGI OGÓLNE}

Europejska Konwencja w sprawie ochrony zwierząt kręgowych wykorzystywanych do celów doświadczalnych i innych celów naukowych oraz dyrektywa 2010/63/UE wraz z aktami wykonawczymi konstytuują europejski standard doświadczeń na zwierzętach, który opiera się na podstawowych zasadach ogólnych oraz szczegółowych wymogach obowiązujących przy w ocenie dopuszczalności oraz przeprowadzaniu doświadczeń ${ }^{12}$.

Aksjologiczną podstawę standardu stanowi wyraźnie wyartykułowana $\mathrm{w}$ nowej dyrektywie zasada 3R od ang. replacement, reduction, refinement czyli zastapienia, zmniejszenia $i$ doskonalenia. W skrócie rzecz ujmując oznacza ona zastępowanie doświadczeń na żywych zwierzętach innymi sposobami badawczymi, zmniejszenie liczby zwierząt używanych do doświadczeń oraz doskonalenie metod hodowli i metod badawczych w celu złagodzenia bólu, cierpienia i stresu zwierząt doświadczalnych ${ }^{13}$. Wymogi te były już po części uwzględnione zarówno w konwencji jak i w starej dyrektywie 86/609/EWG. Jednakże nowy akt, zgodnie z przyjętym w 2005 roku przez Komisję Europejską planem działań w zakresie dobrostanu zwierząt, rozwija i precyzuje wcześniejsze regulacje, i co najważniejsze, stwarza efektywniejsze instrumenty służące do ich rygorystycznej realizacji.

W nowej dyrektywie ochroną objęte zostały już nie tylko kręgowce, wraz z ich formami płodowymi, ale również głowonogi. Te ostatnie, jak przykładowo kałamarnice, ośmiornice, zostały objęte zakresem obowiązywania dyrektywy 2010/63/UE ze względu na uzasadniony wynikami badań naukowych sto-

12 Por. W. Radecki, Ustawa o ochronie zwierząt: komentarz, Warszawa 2012, s. 195.

13 Ibidem, s. 198. 
pień rozwoju układu nerwowego, a co za tym idzie zdolność odczuwania i inteligencji ${ }^{14}$.

Dyrektywa 2010/63/UE rezygnuje też ze stosowania terminu doświadczenie ${ }^{15}$, którym posługiwały się zarówno konwencja jak i dyrektywa 86/609/EWG, zastępując je szerszym znaczeniowo terminem - procedura. Oznacza ona: ,jakiekolwiek inwazyjne lub nieinwazyjne wykorzystanie zwierzęcia do celów doświadczalnych lub innych naukowych - o znanym lub nieznanym wyniku ${ }^{16}$, lub celów edukacyjnych, które może spowodować u zwierzęcia ból, cierpienie, dystres [stres przewlekły - M.M.] lub trwałe uszkodzenie w stopniu równym ukłuciu igłą lub intensywniejszym, zgodnie z dobrą praktyką weterynaryjną. Obejmuje to wszelkie czynności mające na celu lub mogące spowodować urodzenie się lub wylęg zwierzęcia lub stworzenie i utrzymanie zmodyfikowanej genetycznie linii zwierząt w każdym z takich warunków, ale wyklucza uśmiercanie zwierząt wyłącznie po to, aby wykorzystać ich narządy lub tkanki".

Uzasadnieniem procedury może być tylko cel zasługujący na aprobatę i wyraźnie przewidziany jako dopuszczalny czy to wkonwencji czy to w dyrektywie. Według dyrektywy 2010/63/UE takim celem może być jeden lub kilka z wyliczonych art. 5: a) badania podstawowe; b) badania translacyjne ${ }^{17}$ lub stosowane ${ }^{18}$

14 T. Pietrzykowski, op. cit., s. 1.

15 Pojęcie to miało węższy zakres, akcentujący aspekty inwazyjności działania. Stosownie do przepisów dyrektywy „doświadczenie” oznaczało „jakiekolwiek wykorzystanie zwierzęcia do celów doświadczalnych lub innych naukowych, które mogło u niego spowodować ból, cierpienie, niepokój lub trwałe uszkodzenie, łącznie z wszelkimi czynnościami mającymi na celu lub powodującymi urodzenie się zwierzęcia w każdej takiej sytuacji, ale z wyłączeniem najmniej bolesnych sposobów zabijania lub znakowania zwierząt przyjętych w nowoczesnej praktyce (tj. metod „humanitarnych”)”.

${ }_{16}$ To przykładowo cele osiągane w szkołach wyższych w ramach ćwiczeń laboratoryjnych.

17 Naukowe badania genetyczne.

18 Prace badawcze podejmowane w celu zdobycia nowej wiedzy mającej konkretne zastosowania praktyczne. Polegają one bądź na poszukiwaniu możliwych zastosowań praktycznych dla wyników badań podstawowych bądź na poszukiwaniu nowych rozwiązań pozwalających na osiągnięcie z góry założonych celów praktycznych. Wynikami badań stosowanych są modele próbne 
prowadzone w którymkolwiek z następujących celów: (i) unikanie, zapobieganie, diagnozowanie lub leczenie choroby, złego stanu zdrowia lub innej nieprawidłowości lub ich skutków u ludzi, zwierząt lub roślin; (ii) ocena, wykrywanie, regulacja lub modyfikacja stanów fizjologicznych u ludzi, zwierząt lub roślin; lub (iii) dobrostan zwierząt i poprawa warunków hodowli zwierząt hodowanych w celach rolniczych; c) badania prowadzone w którymkolwiek z celów określonych w lit. b) w opracowywaniu i produkcji leków, środków spożywczych, pasz i innych substancji lub produktów lub badania ich jakości, skuteczności i bezpieczeństwa ich stosowania; d) ochrona środowiska naturalnego w interesie zdrowia lub dobrostanu ludzi lub zwierząt; e) badania mające na celu zachowanie gatunku; f) kształcenie na poziomie szkolnictwa wyższego lub szkolenia w celu nabycia, utrzymania lub doskonalenia umiejętności zawodowych; g) badania z zakresu medycyny sądowej.

$\mathrm{Z}$ artykułu 1 ust. 5 pkt b wynika jednak, że dyrektywa nie ma zastosowania do klinicznych badań weterynaryjnych mających na celu dopuszczenie do obrotu produktu leczniczego. Oznacza to, że testowanie na zwierzętach leków weterynaryjnych nie podlega przepisom dyrektywy. Wyłom ten trzeba uznać za w najwyższym stopniu dyskusyjny i trudny do pogodzenia zasadami konwencji i samej dyrektywy ${ }^{19}$. Zważywszy na fakt, że badania kliniczne leków dla ludzi podlegają przepisom dyrektywy sądzić można, że dysproporcja w regulacji jest efektem skutecznego lobbingu koncernów produkujących leki weterynaryjne.

\subsection{ZASADA ZASTAQPIENIA}

Zasada zastąpienia, inaczej (subsydiarności) - polega na tym, że procedura doświadczalna lub naukowa dla któregokolwiek z dozwolonych celów może zostać przeprowadzona tylko

wyrobów, procesów czy metod, np. identyfikowanie przeciwciał związanych z konkretnymi chorobami http://www.stat.gov.pl/gus/definicje.

19 T. Pietrzykowski, op. cit., s. 1. 
wtedy, jeżeli racjonalnie i praktycznie nie jest możliwe wykorzystanie innej zadowalającej z naukowego punktu widzenia metody - niewymagającej używania zwierząt (art. 6 ust. 1 konwencji). Inaczej mówiąc doświadczenia nie mogą być przeprowadzane jeżeli istnieje zadowalająca pod względem naukowym metoda lub strategia badawcza nieobejmująca wykorzystywania żywych zwierząt (art. 4 ust 1 dyrektywy). Praktycznej realizacji tej zasady służy przewidziane zarówno w konwencji jak i w dyrektywie uznawanie tak dalece jak to możliwe ważności danych czy wyników doświadczeń przeprowadzonych w innych państwach aby uniknąć niepotrzebnego powtarzania doświadczeń. W tym też celu ustanowiono w 1991 r. unijne laboratorium referencyjne ds. walidacji metod alternatywnych pod nazwą Europejski Ośrodek Walidacji Metod Alternatywnych $\left(\mathrm{ECVAM}^{20}\right)$.

\subsection{ZASADA ZMNIEJSZENIA}

Zasada zmniejszenia oznacza, że w procedurach doświadczalnych i naukowych należy wykorzystywać jak najmniejszą ilość zwierząt (art. 4 ust. 2 dyrektywy). Liczbę tę można zredukować poprzez wykonywanie procedur na zwierzętach wielokrotnie o ile nie godzi $\mathrm{w}$ dobrostan zwierząt. Z zasadą zmniejszenia wiążą się wprowadzone zarówno w konwencji jak i w dyrektywie ograniczenia przedmiotowe trojakiego rodzaju.

Po pierwsze do doświadczeń mogą być używane tylko zwierzęta pochodzące z hodowli. Listę tych zwierząt określają załączniki do konwencji i dyrektywy, które wymieniają następujące gatunki: szczur, świnka morska, chomik złoty (syryjski), królik, pies, kot, żaba i in. Pomimo postulatów środowisk prozwierzęcych domagających się całkowitego zakazu doświadczeń na ssakach naczelnych lista zwierząt hodowlanych określona załącznikiem II zawiera również różne gatunki małp. Jednakże nowe prawo unijne wprowadza liczne ograniczenia rodzajów doświadczeń do jakich mogą być one wykorzystywane. Ze względu na bliskość gatunkową oraz zaawansowane umiejętno-

20 Dostępny w Internecie http://ecvam.jrc.it/. 
ści społeczne i behawioralne wykorzystywanie małp powinno być dozwolone wyłącznie na użytek badań mających na celu zachowanie tych gatunków oraz dla ratowania życia i zapobiegania przewlekłej niepełnosprawności ludzi - i to jeśli żaden inny gatunek ani żadna alternatywna metoda nie są wystarczające dla spełnienia celów danej procedury.

Po drugie, istnieje względny zakaz wykorzystywania do doświadczeń zwierząt dzikich od którego mogą być przewidziane wyjątki w prawie krajowym (art. 21 ust.1 konwencji i art. 9 ust.1 dyrektywy). Odnośnie zwierząt dzikich zagrożonych gatunkowo (art. 7 dyrektywy) dyrektywa nakazuje wprowadzenie zakazu doświadczeń z wykorzystaniem gatunków uznanych za zagrożone zgodnie ze stosownymi załącznikami do Konwencji o międzynarodowym handlu dzikimi zwierzętami i roślinami gatunków zagrożonych wyginięciem ${ }^{21}$ i roślin oraz do rozporządzenia wdrażającego tę konwencję ${ }^{22}$, chyba że pozostają one w zgodzie z rozporządzeniem, a przedmiotem doświadczeń są badania mające na celu zachowanie danego gatunku lub podstawowe cele biomedyczne, jeżeli dany gatunek wyjątkowo okazuje się jedynym przydatnym do tych celów.

Po trzecie istnieje względny zakaz wykorzystywania do doświadczeń zwierząt bezdomnych w szczególności psów i kotów, ponieważ cechy zbłąkanych i zdziczałych zwierząt z gatunków domowych nie są znane, a pozyskiwanie i umieszczanie w ośrodkach zwiększa dystres u takich zwierząt (art. 21 ust. 3 konwencji oraz art. 19 ust.4 dyrektywy).

\subsection{ZASADA DOSKONALENIA}

Zasada doskonalenia polega na poprawie warunków hodowli, utrzymania zwierząt i opieki nad nimi, jak również metod

${ }^{21}$ Konwencja o międzynarodowym handlu dzikimi zwierzętami i roślinami gatunków zagrożonych wyginięciem, sporządzona w Waszyngtonie dnia 3 marca 1973 r., Dz. U. z 1991 r. Nr 27, poz. 112.

22 Rozporządzenie Rady (WE)nr 338/97z dnia 9 grudnia 1996 r. w sprawie ochrony gatunków dzikiej fauny i flory w drodze regulacji handlu nimi, Dz. Urz. UE L 61 z 3.3.1997 r. 
stosowanych $\mathrm{w}$ procedurach, tak aby wszelki potencjalny ból, cierpienie, dystres lub trwałe uszkodzenie zostały wyeliminowanie lub ograniczone do minimum. I tak, odnośnie warunków hodowli dyrektywa w nowy sposób reguluje wymogi dotyczące warunków utrzymywania zwierząt doświadczalnych - obszerny załącznik III szczegółowo wskazuje nowe, większe wymiary pomieszczeń i klatek wymaganych w celu zapewnienia zwierzętom doświadczalnym znośnych warunków bytowych ${ }^{23}$.

Natomiast odnośnie doskonalenia procedur doświadczalnych zasadą jest, że w przypadku dokonywania wyboru pomiędzy procedurami należy preferować metody które: wykorzystują jak najmniejszą liczbę zwierząt, wykorzystują zwierzęta z najniższą wrażliwością neurofizjologiczną, powodują jak najmniej bólu, cierpienia, dystresu lub trwałego uszkodzenia oraz z największym prawdopodobieństwem przyniosą zadowalające wyniki. Z realizacją tej reguły wiąże się też względny nakaz wymóg przeprowadzania procedur $\mathrm{w}$ znieczuleniu ogólnym lub miejscowym. Zwłaszcza procedur, w których dochodzi do poważnych uszkodzeń, mogących spowodować dotkliwy ból, nie wolno przeprowadzać bez znieczulenia (art. 14 dyrektywy).

W związku z regułą doskonalenia metod załącznikiem VIII do dyrektywy wprowadza się ujednoliconą skalę inwazyjności doświadczeń. Wcześniej skalę tą ustalano w ramach kompetencji krajowych. Ujednolicenie skali i relatywizacji sposobu kontroli etycznej doświadczenia w zależności od stopnia jego inwazyjności było jednym z najistotniejszych postulatów de lege ferenda dotyczących międzynarodowych standardów ochrony zwierząt wykorzystywanych do celów doświadczalnych ${ }^{24}$. Obok trzech podstawowych stopni inwazyjności - łagodnego, umiarkowanego i dotkliwego, przewiduje ona dodatkowo odrębną kategorię doświadczeń „terminalnych, bez odzyskania przy-

23 Choć zwierzętarnie i inne miejsca utrzymywania zwierząt przeznaczonych do doświadczeń mają na spełnienie nowych wymogów 7 lat, niemal całkowita wymiana standardowego wyposażenia tych obiektów pociągnie za sobą z pewnością ogromne nakłady finansowe, szacowane w skali całej UE nawet na kilka miliardów euro. T. Pietrzykowski, op. cit., s. 2.

24 Ibidem. 
tomności" (przeprowadzanych przy całkowitym znieczuleniu). Należy także zauważyć, że pewna, najłagodniejsza grupa doświadczeń zostaje w istocie w ogóle wyłączona z zakresu zastosowania dyrektywy na mocy zawartego w definicji „doświadczenia” zastrzeżenia, że nie stanowią go procedury, w których poziom bólu, cierpienia lub dystresu zwierzęcia jest niższy niż w przypadku ukłucia go igłą. Z drugiej strony, także poza podstawową skalą inwazyjności określoną w załączniku VIII, na podstawie przepisów dyrektywy można skonstruować dodatkowo grupę doświadczeń w najwyższym stopniu inwazyjnych, które wiążą się z dotkliwym bólem, cierpieniem lub dystresem, który może mieć charakter długotrwały i którego nie da się złagodzić (art. 15 ust. 2). Istotnym novum dyrektywy jest niemal bezwyjątkowy zakaz wykonywania takich doświadczeń. Opiera się to na wyrażonym w preambule do dyrektywy założeniu, że istnieje pewna maksymalna granica bólu i cierpień, których nie można usprawiedliwić moralnie jakimikolwiek wartościami i celami o charakterze naukowym czy poznawczym. W istocie więc realna skala inwazyjności wynikająca z przepisów dyrektywy obejmuje aż 6 kategorii - obok czterech wprost zdefiniowanych w załączniku VIII, także doświadczenia tak mało bolesne lub stresujące, że w ogóle nie podlegające dyrektywie oraz skrajnie inwazyjne, których wykonywanie objęte jest, co do zasady - zakazem ${ }^{25}$.

Z zasadą doskonalenia wiążą się również wprowadzone dyrektywą 2010/63/UE nowe wymogi kwalifikacji personelu odpowiedzialnego za utrzymywanie zwierząt u hodowców, dostawców i jednostek doświadczalnych, a także planowanie i przeprowadzanie doświadczeń oraz nadzór nad dobrostanem zwierząt i odpowiedzialnym za nie personelem. Przepisy unijne wymagają aby osoby odpowiedzialne w jednostce doświadczalnej za nadzór nad przebiegiem doświadczenia przerywały każdy zbędny ból, cierpienie lub dystres zwierzęcia podczas jego wykonywania oraz zapewniały zgodność faktycznego sposobu wykonania doświadczenia z projektem na jaki wydana została zgoda komisji etycznej, zaś w razie potrzeby - podejmowały sto-

25 Ibidem. 
sowną reakcję. Sposób konstrukcji tych przepisów wskazuje, że ma ona zostać przeniesiona do krajowych porządków prawnych w sposób zapewniający skuteczne egzekwowanie jej postanowień. Wiąże się to z powszechnie wytykaną „piętą achillesową” ustawodawstwa ochrony zwierząt w bardzo wielu państwach, tj. niewielkim stopniem jego praktycznego przestrzegania i brakiem dostatecznie efektywnych mechanizmów jego egzekwowania i sankcjonowania. Znamiennym tego przykładem mogą być aktualnie obowiązujące w ustawie o doświadczeniach na zwierzętach przepisy o kontroli prawidłowości przeprowadzania doświadczeń w jednostkach doświadczalnych. Obowiązek takiej kontroli (mający charakter lex imperfecta) powierzony został lokalnym komisjom etycznym. Częstotliwość takich kontroli waha się w zależności od komisji od kilkunastu przypadków rocznie do zera. Wszystkie przeprowadzane kontrole dokonywane są za 7-dniowym uprzedzeniem kontrolowanej jednostki. W tej sytuacji realna możliwość wykrycia ewentualnych naruszeń, a co za tym idzie, także liczba przypadków stosowania zawartych w ustawie norm sankcjonujących jest $\mathrm{w}$ istocie śladowa, o ile nie zerowa. Postanowienia prawa krajowego maja zatem nie tylko formalnie wprowadzić do wewnętrznych porządków prawnych instytucje kreowane dyrektywą, ale mają czynić to w sposób praktycznie efektywny. Świadczy o tym również konieczność wprowadzenia w regulacjach krajowych skutecznych, proporcjonalnych i odstraszających sankcji za naruszenie przepisów implementujących dyrektywę ${ }^{26}$.

\section{WYMÓG ZEZWOLENIA KOMPETENTNEGO ORGANU NA PRZEPROWADZENIE PROCEDUR}

Bezwzględnym wymogiem zawartym zarówno w konwencji jak i w dyrektywie 2010/63/UE jest uzależnienie przeprowadzania doświadczeń od stosownych zezwoleń kompetentnego

\footnotetext{
26 Ibidem.
} 
organu, wydawanych tylko osobom mającym właściwe kwalifikacje ${ }^{27}$. W świetle dotychczasowych unormowań krajowych organami wyrażającymi zgodę na procedury są lokalne komisje etyczne działające przy kilku ośrodkach badawczych oraz Krajowa Komisja Etyczna - jako organ odwoławczy.

Jednocześnie nowa dyrektywa nakazuje by w procesie podejmowania decyzji zezwalającej na procedurę kierować się zasada cost-benefit analysis, będącą fundamentem etycznej oceny doświadczenia. Polega ona na ważeniu oczekiwanych korzyści naukowych lub poznawczych danej procedury i koniecznej dla ich osiągnięcia „ceny” cierpień i bólu zwierzą ${ }^{28}$.

Warto zauważyć, że przepisy dyrektywy zasadniczo mają zastosowanie $\mathrm{w}$ stosunku do zwierząt hodowanych wyłącznie po to, aby ich narządy lub tkanki mogły być wykorzystane do celów naukowych, jednakże uśmiercanie tych zwierząt w celu pozyskania narządów lub tkanek zostało wyłączone z definicji „procedury”. W związku z tym uśmiercenie zwierzęcia, którego tkanki mają być przeznaczone na przykład do ksenostransplantacji $^{29}$ nie będzie wymagało tej zgody komisji etycznej ${ }^{30}$.

\section{WYMÓG TRANSPARENTNOŚCI PODEJMOWANIA DECYZJI}

Nowym wymogiem europejskiego standardu doświadczeń na zwierzętach wprowadzonym dyrektywą 2010/63/UE jest wymóg transparentności. Dyrektywa dąży do zwiększenia jawności i przejrzystości doświadczeń wobec opinii publicznej. Służyć temu mają dwie nowe instytucje - nietechnicznego streszczenia i oceny retrospektywnej. Obligatoryjnie publikowane nietech-

27 W. Radecki, op. cit., s. 197.

28 T. Pietrzykowski, op. cit., s. 2.

29 Ksenotransplantacja oznacza przeszczepienie tkanki lub narządów między osobnikami należącymi do różnych gatunków (np. wymiana uszkodzonej zastawki na zastawkę zwierzęcą).

30 T. Pietrzykowski, op. cit., s. 2. 
niczne streszczenie zawierać ma podstawowe, zrozumiałe dla niespecjalisty informacje na temat celów i przewidywanych korzyści naukowych oraz liczby i rodzajów wykorzystywanych w doświadczeniu zwierząt. Przedmiotem oceny retrospektywnej jest natomiast osiągnięcie założonych przez badacza celów, a także szkody wyrządzone zwierzętom w jego trakcie. Ponadto, ocena retrospektywna obejmować ma ewentualne implikacje doświadczenia dla wdrażania zasady $3 \mathrm{R}^{31}$.

\section{ZAKOŃCZENIE}

W obecnym stanie prawa międzynarodowego, unijnego i porządku krajowego eksperymenty na zwierzętach są dopuszczalne pod warunkiem, że cel tych doświadczeń jest prawowity, cierpienie fizyczne i psychiczne zwierzęcia jest optymalnie ograniczone i nie ma żadnej alternatywnej możliwości przeprowadzenia tych badań. Jak pisze W. Radecki: „badania takie są niewątpliwie złem, ale można je usprawiedliwić moralnie"32.

Jak wskazano wyżej, pierwszym aktem ustanawiającym zasady europejskiego standardu doświadczeń na zwierzętach była Europejska Konwencja w sprawie ochrony zwierząt kręgowych wykorzystywanych do celów doświadczalnych i innych celów naukowych z 1986 r. Zastanawiającym jest przy tym fakt, że pośród Państw Stron tego traktatu brakuje Szwajcarii - światowego lidera przemysłu farmaceutycznego i medycznego. Będąc poza strukturami UE Szwajcaria nie jest również zobowiązana do wdrożenia wymogów dyrektywy 2010/63/UE. Zatem obowiązuje tam wyłącznie reżim wewnętrzny, nie podlegający międzynarodowej standaryzacji, który ze względu na zachowanie konkurencyjności na światowym rynku leków i produktów medycznych, może być znacznie niższy niż standard unijny. O szczególnie niepokojącej sytuacji w laborato-

3/2012 31 Ibidem.

32 Por. W. Radecki, op. cit., s. 198. 
riach szwajcarskich donoszą publikacje tamtejszych obrońców praw zwierzą ${ }^{33}$.

Natomiast dla państw UE konwencja a zwłaszcza uszczegółowiająca jej wymogi dyrektywa 2010/63/UE stanowią niewątpliwy krok naprzód kreując wyższy standard etycznego traktowania zwierząt laboratoryjnych. Nowe prawo unijne wymaga zasadniczej poprawy w krajach, w których obowiązujące ustawodawstwo nie wykroczyło poza minimalne wymogi określone w poprzednio obowiązującej dyrektywie z 1986 r. W przypadku ustawodawstwa polskiego regulacje dyrektywy wydają się wymuszać przede wszystkim poprawę systemu nadzoru etycznego nad doświadczeniami na zwierzętach. Wprowadzenie w życie przepisów dyrektywy wiąże się także z koniecznością silnego wzmocnienia infrastrukturalnego lokalnych komisji etycznych, zwłaszcza jeśli miałyby one nadal pozostać także organami kontroli nad jednostkami doświadczalnymi. Z uwagi na konieczność dostosowania w najbliższych czasie kwalifikacji osób zajmujących się zwierzętami doświadczalnymi, niezbędne jest stosunkowo szybkie zorganizowanie i podjęcie stosownych inicjatyw edukacyjnych i szkoleniowych.

Kontakt e-mail:

m.micinska@kpsw.edu.pl

33 Por. M. Schär-Manzoli, M. Keller, Holocaust. Wiwisekcja dzisiaj, Warszawa 2011. 